\title{
Distinct microalgae species for food-part 2: comparative life cycle assessment of microalgae and fish for eicosapentaenoic acid (EPA), docosahexaenoic acid (DHA), and protein
}

\author{
S. Schade ${ }^{1}$ (D) G. I. Stangl ${ }^{1,2} \cdot$ T. Meier $^{1,2}$
}

Received: 8 January 2020 / Revised and accepted: 9 June 2020 / Published online: 7 July 2020

(C) The Author(s) 2020

\begin{abstract}
The production of food for a growing world population is a great challenge. In particular, protein and the long-chain n-3 fatty acids, eicosapentaenoic acid (EPA), and docosahexaenoic acid (DHA), which exert a series of potential health effects, are scarce resources in the context of global food security. Fish from wild capture and aquaculture production cannot meet the current demand for EPA and DHA; therefore, a supplementation with alternative sources is crucial. Specific microalgae species have been shown to be a lucrative source of EPA, DHA, and protein, in particular, the oleaginous microalgae Nannochloropsis sp. and Phaeodactylum tricornutum. This study aimed to compare different cultivation scenarios of Nannochloropsis sp. and P. tricornutum with the production of aquaculture and capture fish as traditional sources of EPA and DHA in terms of environmental impacts. Scenarios included borosilicate glass and acrylic glass as photobioreactor (PBR) materials, two different tube diameters, and three different cultivation seasons. In these scenarios, carbon dioxide was modeled as an avoided burden. Additionally, all scenarios were modeled with the burdens resulting from carbon dioxide production. Environmental impacts of selected fish species were obtained from systematic literature research. Life cycle assessment following ISO 14040/44 was used to analyze the global warming potential, acidification, eutrophication, cumulative energy demand, water footprint, and land use. The system boundaries were set from "cradle-to-store," where the target store is located in Germany. Microalgae biomass as a source of EPA, DHA, and protein was found to have similar or lower environmental impacts than fish fillet from wild capture and aquaculture production when carbon dioxide was modeled as an avoided burden. Microalgae production that included the full burden of carbon dioxide production still caused similar or lower environmental impacts than aquaculture fish. It was found that the distinct microalgae species can significantly influence the results if the comparison is conducted based on nutritional values. Regarding the recommended daily intake of 250-500 mg EPA+DHA, microalgae are an advisable source of nutrients to lessen the environmental pressure on marine ecosystems.
\end{abstract}

Keywords Microalgae cultivation · LCA · Global warming · Environmental impacts · Nannochloropsis sp. · Photobioreactor · PBR

Electronic supplementary material The online version of this article (https://doi.org/10.1007/s10811-020-02181-6) contains supplementary material, which is available to authorized users.

S. Schade

susann.schade@landw.uni-halle.de

1 Institute for Agricultural and Nutritional Sciences, Martin Luther University Halle-Wittenberg, Von-Danckelmann-Platz 2, 06120 Halle (Saale), Germany

2 Competence Cluster for Nutrition and Cardiovascular Health (nutriCARD), Jena, Halle and Leipzig, Germany

\section{Introduction}

Protein and the long-chain n-3 polyunsaturated fatty acids (PUFAs) eicosapentaenoic acid (EPA), and docosahexaenoic acid (DHA) are already scarce nutrients in a global context, with the main sources being meat and fish, whereby meat in particular causes relatively high environmental impacts (Meier and Christen 2012; Clune et al. 2017). Fish catch and aquaculture, on the other hand, cannot meet the actual global demand of EPA and DHA. It has been calculated that based on a daily individual intake of $500 \mathrm{mg}$ EPA+DHA (Salem and Eggersdorfer 2015; Ma et al. 2016), the annual global gap between EPA+DHA demand and supply amounts to 1.1 million $t$, which signifies that fish only contribute $15 \%$ of the 
global demand of these nutrients (Salem and Eggersdorfer 2015). Krill, an alternative source for these omega-3 PUFAs, currently contributes only $0.3 \%$ of the demand, whereby production could possibly be increased to supply $8-9 \%$ (Salem and Eggersdorfer 2015). Thus, it is very relevant to investigate additional alternative sources of these essential nutrients.

Some microalgae species contain a high quantity of $n-3$ PUFAs with concentrations comparable with those found in fish oil (Chacón-Lee and González-Mariño 2010). The quality of proteins from microalgae has been shown to be equal to that of proteins from soybean (Becker 2007). In addition, some microalgae species show a wide range of favorable highvalue nutrients such as vitamins, carotenoids, phycobilins, polysaccharides, and sterols (Keller et al. 2017). Hence, these species could potentially help compensate for the global deficiency of nutrient supply or to improve health. Nannochloropsis sp. is an oleaginous microalga with an average EPA content of $4.2 \%$ and a protein content of approximately $30 \%$ in dry biomass (Rebolloso-Fuentes et al. 2001; Fábregas et al. 2004; Kent et al. 2015; Ma et al. 2016; Paes et al. 2016; Hulatt et al. 2017; Molino et al. 2018). Thus, it is a promising species as a source for PUFAs and protein.

In the first part of this study (Schade and Meier 2020), microalgae cultivation in a "cold weather" climate was assessed using different scenarios. However, it is difficult to explore the full potential of microalgae as a nutrient source without comparison with alternative food groups. Hence, in this part of the study, those scenarios are compared with a variety of fish products as conventional nutrient sources. To conduct a realistic and objective comparison, 15 new scenarios have been added to the 15 scenarios from the first part of the study. These additional scenarios consider microalgae cultivation with the use of synthetic carbon dioxide so that carbon dioxide is not modeled as an avoided burden. For this purpose, different functional units are applied, including the content of relevant nutrients (PUFAs and protein), because conventional food groups are mostly assessed in fresh product weight, while microalgae are commonly evaluated on a dry weight basis. More specifically, the functional units of $100 \mathrm{kcal}$, $50 \mathrm{~g}$ protein, and $0.5 \mathrm{~g}$ EPA+DHA were used. The application of different nutrient-based functional units enables a direct and fair comparison of the two food groups "microalgae" and "fish." This procedure of analyzing and comparing different units has been used in previous studies on the environmental impacts of different food groups (Parodi et al. 2018; Poore and Nemecek 2018). The usage of these units furthermore assures that the comparison covers both PUFAs and protein, as fish is not only the most important source for PUFAs but also a great protein source. The different functional units will additionally serve as a good basis for streamline calculations in further studies.

Concerning the environmental impacts of fish, systematic literature research was conducted, and LCIA (life cycle impact assessment) values for fish fillets from different species and production methods were obtained. The choice of fish species was based on consumption habits in Germany. The ten most important fish species according to total consumption were selected for the literature research. Concerning production methods, aquaculture and capture production were distinguished.

Here we performed an extensive comparison of microalgae to different fish species regarding the nutritional profile, in particular n-3 PUFAs and protein. This comparison could contribute to evaluating the benefits of microalgae as a food component for human nutrition. Additionally, this study aims to compare the modeling of carbon dioxide as an avoided burden to the inclusion of the full burden of carbon dioxide production during microalgae cultivation. Previous studies have often relied on the usage of waste carbon dioxide originating from sources in close proximity to microalgae to ameliorate the environmental cycle of microalgae (Kadam 2001; Batan et al. 2013; Zaimes and Khanna 2013; Smetana et al. 2017; Collotta et al. 2018). However, this approach does not consider the situations in many microalgae facilities. The current comparative study may help gain more insight into the consequences of this methodological choice.

This is the second part of a two-part study to analyze the environmental impacts of industrial-scale microalgae cultivation in photobioreactors in a "cold weather" climate. The comprehensive evaluation of microalgae as novel food ingredients includes life cycle assessments (LCAs) as well as the evaluation of their nutritional value in comparison with those of other common foods. Part 1 (Schade and Meier 2020) included a complete LCA according to ISO 14040/44 to assess microalgae cultivation in a tubular photobioreactor. Thus, input flows during microalgae cultivation were assessed precisely, allowing modeling of the variance of multiple parameters. Furthermore, the model was tested in a sensitivity analysis applying different relevant scenarios, including different tube diameters and materials, cultivation season lengths, and two different microalgae species (Nannochloropsis sp. and Phaeodactylum tricornutum).

\section{Materials and methods}

\section{LCA framework}

\section{Goal and scope}

As the objective of the study, the environmental impacts from microalgae production were compared with those from traditional products containing relevant nutrients, namely, different fish fillet products. The comparison was performed based on the nutrient content in the final products, more specifically, the calorific value, the amount of polyunsaturated fatty acids EPA 
and DHA, and the amount of protein. Concerning microalgae cultivation, a variety of scenarios from the preceding part of the study (Schade and Meier 2020) were selected and tested for their comparability to fish. The included scenarios comprised variations in reactor design, the choice of microalgae species, and different cultivation season lengths due to climatic preconditions. For every scenario, three different cultivation seasons were assumed, which were then illustrated as a range for each scenario. Thus, cultivation of Nannochloropsis sp. in 40-mm (baseline) and 36-mm borosilicate glass tubes was analyzed, along with the usage of acrylic glass in a 3-year and 7-year cycle. Furthermore, the cultivation of $P$. tricornutum in 40-mm borosilicate glass tubes was observed. Additionally, 15 further scenarios were assessed in order to obtain a realistic and fair comparison of microalgae and fish. These cases were based on the scenarios of part 1 of the study, but with the full burden of carbon dioxide production whereas in the first 15 scenarios, carbon dioxide was modeled as an avoided burden. Thus, as a secondary goal, the consequences from this important methodological choice were assessed.

\section{Modeling approach}

An attributional modeling approach was applied with allocation "at the point of substitution" to enable a fair integration of the recycling stage. Waste treatment, including recycling, was modeled for all reactor materials. For all scenarios, carbon sequestration during cultivation was modeled both as an avoided burden and with the full impact of carbon dioxide production.

\section{System boundaries}

Concerning the microalgae life cycle, system boundaries comprised all processes up to the dry microalgae biomass at the store. The system boundaries for microalgae cultivation are illustrated in Fig. 1. In terms of fish products, three different system boundaries were initially recorded (at the farm gate, at the harbor of the target country, at the store), which were harmonized to fish fillet at the store by adding data for transportation processes to the farm gate data (the farm gate includes "landed fish"). Germany was assumed to be the target country for all products. The applied system boundaries of fish are shown in Fig. 2. Hence, a cradle-to-store system boundary was applied for this study.

\section{Functional unit}

Several functional units were used for different stages of the LCA. For the methodological calculations and the compilation of the life cycle inventory, $1 \mathrm{~kg}$ DM (dry mass) was used as the functional unit for microalgae because dry biomass was chosen to be the final product in this study. For fish, $1 \mathrm{~kg}$ of fresh fish fillet was chosen as a basis for calculation as all impact values were given for the fresh biomass. To compare microalgae and fish, the same nutrient-based functional units were applied to both products. The life cycle impact assessment was first based on the nutritional energy value to compare the results, namely, $100 \mathrm{kcal}$. Additionally, to obtain a profound comparison, the incorporated amount of protein and polyunsaturated fatty acids (EPA+DHA) was depicted in terms of $50 \mathrm{~g}$ protein and $500 \mathrm{mg} \mathrm{EPA}+\mathrm{DHA}$, which on average correspond to the daily intake recommendations per
Fig. 1 System boundaries of microalgae cultivation (adapted from part 1 of the study)

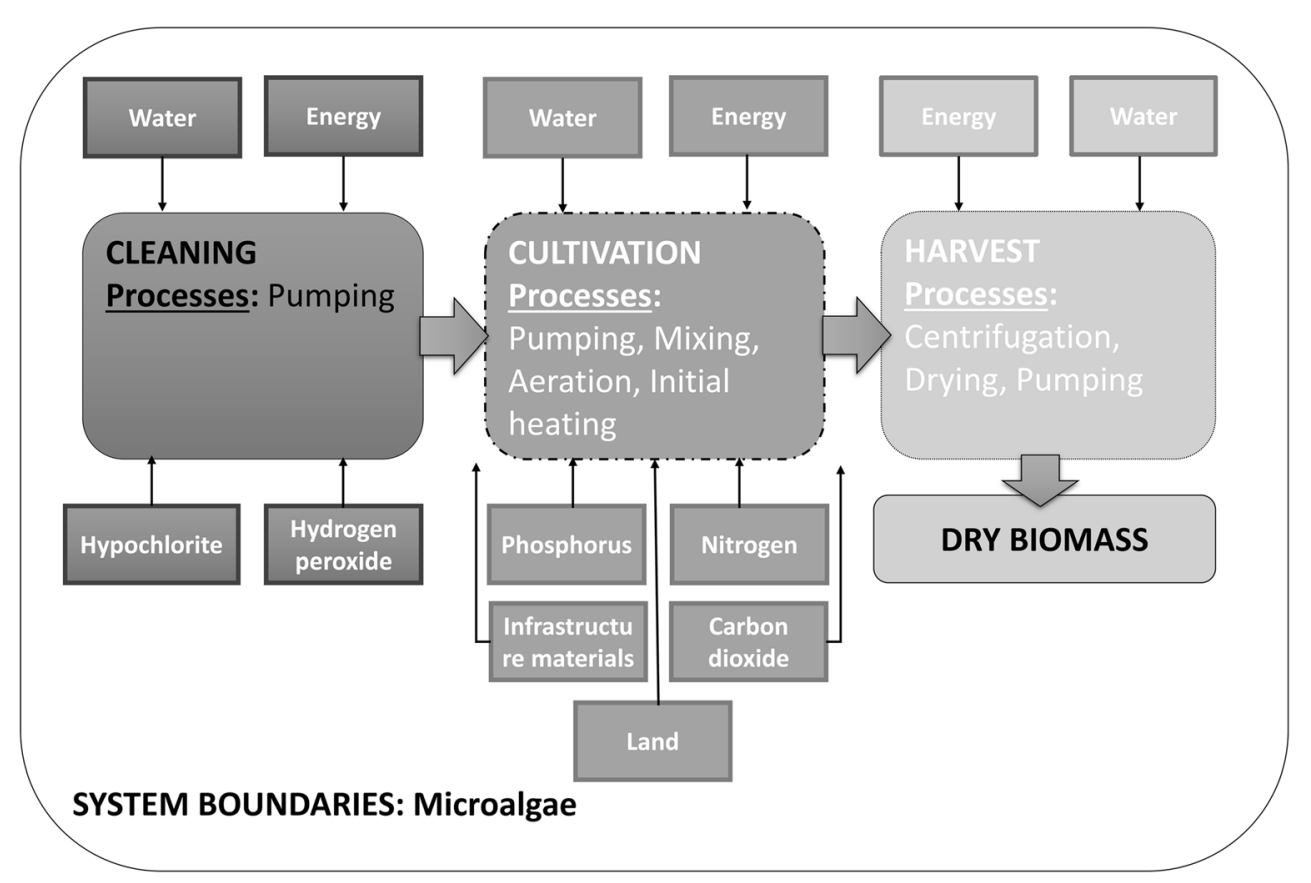


Fig. 2 System boundaries of aquaculture and capture fish production

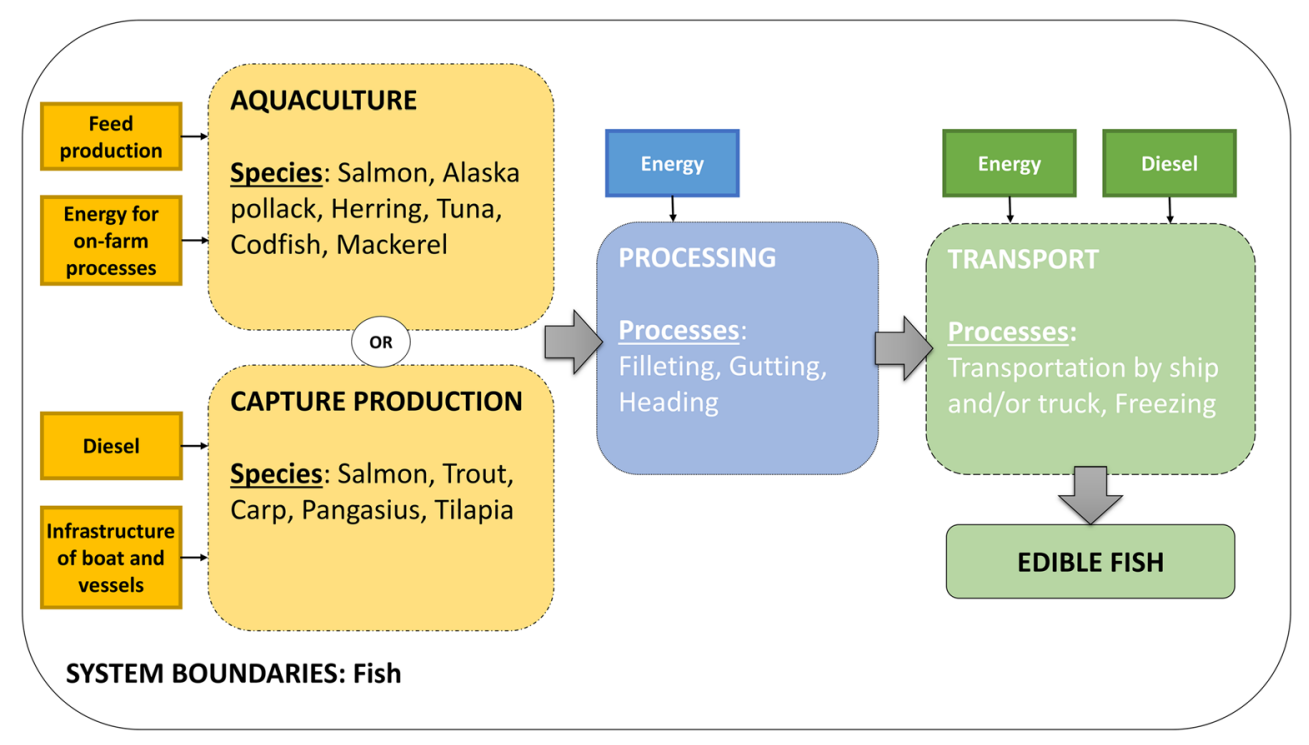

person (World Health Organization (WHO) 2007; Salem and Eggersdorfer 2015). Fish are not only the most important source of PUFAs but also a significant food group for the supply of protein, which is why a comparison was chosen that considers both of these nutrients. No allocation method has been applied for the use of the different functional units. All impacts were fully allocated to the particular functional units used.

\section{Data source}

The comparative analysis was based on the life cycle inventory conducted in the first part of this study. Fifteen additional scenarios were assessed that included the usage of synthetic carbon dioxide, for which data were derived from the Ecoinvent database v3.4. Impact data on fish fillet products were obtained from systematic literature research.

\section{Life cycle impact assessment}

For the life cycle impact assessment (LCIA) of the microalgae scenarios, different methods were used that were aligned with the LCIA values obtained for fish from the literature. The most relevant impact categories concerning fish production are global warming, acidification, eutrophication, and cumulative energy demand. In terms of aquaculture fish production, water and land use are also significant. In accordance with part 1 of this study, global warming was assessed as $\mathrm{CO}_{2}$ eq according to IPCC 2013 GWP 100a (IPCC 2014). Acidification and eutrophication were recorded as $\mathrm{SO}_{2}$ eq and $\mathrm{PO}_{4}{ }^{-}$eq, respectively, based on CML-IA Baseline EU25 (de Bruijn et al. 2002). The calculation of the cumulative energy demand was based on the method published by Ecoinvent v2 and expanded by PRé Consultants (Frischknecht et al. 2007). For comparison with the values for blue water use of fish, the water stress index values (Hoekstra et al. 2012) were applied. Land use was calculated directly using the LCI data.

\section{Data quality analysis}

LCIA values of fish products were depicted in boxplots according to species and production method including the minimum and maximum value, the median, and the 10th and 90th percentile. Regarding land and water use, values for fish were analyzed in boxplots for capture and aquaculture production due to the small range of impact values available for these indicators. An in-depth analysis of the data quality of microalgae cultivation was conducted in the first part of the study.

\section{Systematic literature research: fish consumption in Germany}

To compare the environmental impacts of microalgae cultivation with fish products, a systematic review was conducted. Thus, impact assessment values for relevant fish species were searched, with an emphasis on the German market. An overview of the most consumed freshwater and seawater fish species in Germany is presented in Table 1.

Systematic literature research on fish species was conducted in March 2019 using Google Scholar (Tab. S1). As a second stage, reviews on the environmental impacts of fish capture and aquaculture were scanned for additional relevant papers. The types of studies used included peer-reviewed journal articles, master and doctoral theses, environmental product declarations (EPDs), and conference papers. The timeframe for the publication years of studies was set from 2005 to 2019. Papers were included when they contained impact assessment values for the previously determined fish species. The recorded values comprised the global warming potential 
Table 1 Percent consumption of freshwater and seawater fish in Germany in 2017, adapted from Keller 2019; FAO 2019a

\begin{tabular}{|c|c|c|c|}
\hline $\begin{array}{l}\text { Freshwater and } \\
\text { seawater fish }\end{array}$ & $\begin{array}{l}\text { Total consumption, in } \\
2017 \text {, in \% }\end{array}$ & Scientific name & $\begin{array}{l}\text { Capture/ } \\
\text { aquaculture }\end{array}$ \\
\hline Salmon & 19.0 & Salmo salar & Both \\
\hline Alaska pollack & 17.5 & $\begin{array}{l}\text { Gadus chalcogrammus (old: Theragra } \\
\text { chalcogramma) }\end{array}$ & Capture \\
\hline Herring & 16.2 & Clupea harengus & Capture \\
\hline Tuna & 14.3 & Katsuwonus pelamis & Capture \\
\hline Trout & 7.1 & Salmo trutta & $\begin{array}{l}\text { Aquaculture } \\
\text { mostly }\end{array}$ \\
\hline Pollack & 3.3 & Pollachius spp. & Capture \\
\hline Codfish & 2.5 & Gadus spp. & Both \\
\hline Pangasius & 1.9 & Pangasius spp. & Aquaculture \\
\hline Zander & 1.3 & Sander lucioperca & Both \\
\hline Mackerel & 1.1 & Scomber scombrus & Capture \\
\hline Redfish & 1.0 & Sebastes marinus & Capture \\
\hline Plaice & 0.9 & Pleuronectes platessa & Capture \\
\hline Carp & 0.6 & Cyprinus carpio & Capture \\
\hline
\end{tabular}

in $\mathrm{CO}_{2} \mathrm{eq}$, the acidification potential in $\mathrm{SO}_{2} \mathrm{eq}$, the eutrophication potential in $\mathrm{PO}_{4}{ }^{-}$, the cumulative energy demand (CED) in $\mathrm{MJ}$, the land use in $\mathrm{m}^{2} \mathrm{x}$ year, and the water use in $\mathrm{m}^{3}$ whereas the last two were only relevant in aquaculture production. Data for three different system boundaries were recorded: to the farm gate (comprising capture, processing, and landing of fish), to the harbor of the target country (including the farm gate and transport to the target country), and to the store (including the final product at the store). Processing included decapitating, gutting, filleting, and cooling or freezing. A complete table of all considered studies from the systematic literature research (including omitted scenarios) can be accessed in the supplementary material (Tab. S2).

\section{Harmonization}

Impact assessment values for fish have been harmonized according to the system boundaries and the functional unit. One kilogram of edible fish fillet was used as the basis to calculate the nutritional values. All of the studies from which LCIA values for fish were taken used a mass-based functional unit, and most of them used $1 \mathrm{~kg}$. As the "to store" data were characterized by a great variation in the products, they were excluded, and fish fillets and edible fish were used for comparison means. Similarly, weighted LCIA values were excluded. The "to farm gate" data were used. Studies applying the system boundaries "to the harbor of the target country" sometimes reported transportation data separately which was subtracted in order to also use these data. Data concerning the transport to Germany by sea and/or EURO5 truck were subsequently added through our own calculations. For each country where fish products originated from, the approximate distance to ship the fish products to Germany was obtained using the web tool Pier2Pier (2019). For transport in Germany, an average distance of $378 \mathrm{~km}$ was assumed. The impacts from these transport distances were then calculated with background processes from Ecoinvent. For transoceanic shipping, the process "Transport, freight, sea, transoceanic ship with reefer, freezing $\{$ GLO $\} \mid$ processing | APOS, U" was used. Concerning transport by truck, the process "Transport, freight, lorry 16-32 metric ton, EURO5 \{RER\}| transport, freight, lorry 16-32 tonne, EURO5 | APOS, U” was applied. Not all studies referred to frozen fish; some also referred to fresh fish (Boyd et al. 2011; Mungkung et al. 2013; Chen et al. 2015; Biermann and Geist 2019). However, as the impact due to freezing is most important during transport to the target country, this difference was neglected. Transportation from the country of origin to Germany was calculated separately and thus always included freezing of the products. Consequently, the final LCIA values for fish correspond to the system boundary "cradle-to-store" in Germany.

A harmonization of LCIA values from different LCIA methods was not applied. Most of the studies used IPCC 2007 or CML, which are very similar in their methodological approach. Only a few studies differed in their choice of LCIA method. However, the inclusion of their LCIA values was still considered appropriate, given that all values were illustrated in a cumulative boxplot per species. It has been reported that the LCIA values of commodities are best represented by a range including different producers and countries of origin (Roches et al. 2010). The background processes of the studies from which impact values for fish were derived were considered negligible. The impacts of microalgae cultivation were best represented using Ecoinvent data with the "APOS" approach. 
Concerning fish, the databases or background processes that were used in these studies were not evaluated. Rather, it was assumed that the introduced impact values adequately represented the particular fish products.

\section{Results}

\section{Nutritional profile of microalgae and fish}

The nutritional profiles of the considered microalgae and fish fillet are presented per kg of dry matter content (90\% DM) in Table 2. The two microalgae species investigated showed a similar or slightly smaller calorific value and fat content than the fish species. Concerning the dry matter fat content, only Alaska pollack, codfish, and carp exhibited a smaller share of fat than microalgae, which also affected the share of EPA+ DHA. These three fish species, as well as pangasius, had the lowest share of EPA+DHA, ranging from $3.91 \mathrm{~g} \mathrm{~kg}^{-1} \mathrm{DM}$ for pangasius to $13.71 \mathrm{~g} \mathrm{~kg}^{-1} \mathrm{DM}$ for Alaska pollack. While the two microalgae species are characterized by relatively high amounts of EPA of $31.1 \mathrm{~g} \mathrm{~kg}^{-1} \mathrm{DM}$ for $P$. tricornutum and $42 \mathrm{~g} \mathrm{~kg}^{-1} \mathrm{DM}$ for Nannochloropsis sp., which exceeds the EPA content of all of the fish species analyzed, their share of DHA is rather low. This difference results in an EPA+DHA dry matter content of microalgae that lies in the medium range compared with that of fish fillet. Concerning the dry matter protein content, fish contained significantly higher amounts than microalgae, which even amounted to more than twofold of the protein content found in microalgae.

\section{Energy- and nutrient-specific environmental assessment}

All environmental impact values were depicted in three functional units: $100 \mathrm{kcal}, 0.5 \mathrm{~g}$ EPA+DHA, and $50 \mathrm{~g}$ protein. Values were always depicted with a logarithmic scale in order to provide more precise values in the illustration. Additionally, all figures are presented with a normal scaling in the supplementary material (Figs. S1-S6). The fish fillet products were subdivided into capture production and aquaculture production. Microalgae cultivation was divided into scenarios with avoided $\mathrm{CO}_{2}$ and scenarios with the burden of $\mathrm{CO}_{2}$ production. Thus, five microalgae scenarios each with and without the burden of $\mathrm{CO}_{2}$ production were considered comprising borosilicate glass tubes with 36 and $40 \mathrm{~mm}$ diameter, PMMA (polymethyl methacrylate) tubes with a 3-and 7year lifespan and $P$. tricornutum as an alternative species. For the analysis of the fish and microalgae values, the median values were utilized as a basis for comparison. Exact LCIA values for fish species are included in the supplementary material (Tabs. S8-S13).

\section{Global warming potential}

Concerning the global warming potential of the fish products examined (Fig. 3), the emissions depend highly on the fish species and production type. It appears that aquaculture production tends to have higher $\mathrm{CO}_{2}$ eq emissions than capture production of fish fillets across all FUs. In particular, Pangasius showed high values, with its median reaching a

Table 2 Nutritional profile of microalgae and fish species per kg DM

\begin{tabular}{|c|c|c|c|c|c|c|}
\hline Product & $\begin{array}{l}\text { Calories in } \mathrm{kcal} \mathrm{kg}^{-1} \\
\mathrm{DM}\end{array}$ & $\begin{array}{l}\text { Fat in } \mathrm{g} \mathrm{kg}^{-1} \\
\text { DM }\end{array}$ & $\begin{array}{l}\text { EPA in } \mathrm{g} \mathrm{kg}^{-1} \\
\text { DM }\end{array}$ & $\begin{array}{l}\text { DHA in } \mathrm{g} \mathrm{kg}^{-1} \\
\text { DM }\end{array}$ & $\begin{array}{l}\text { Protein in } \mathrm{g} \mathrm{kg}^{-1} \\
\text { DM }\end{array}$ & $\begin{array}{l}\mathrm{EPA}+\mathrm{DHA} \text { in } \mathrm{g} \mathrm{kg}^{-1} \\
\mathrm{DM}\end{array}$ \\
\hline \multicolumn{7}{|l|}{ Microalgae } \\
\hline Nannochloropsis sp. & 4218.00 & 206.00 & 42.00 & - & 300.00 & 42.00 \\
\hline $\begin{array}{l}\text { Phaeodactylum } \\
\text { tricornutum }\end{array}$ & 4120.00 & 180.00 & 31.10 & 1.40 & 364.00 & 32.50 \\
\hline \multicolumn{7}{|l|}{ Fish: capture production } \\
\hline Salmon & 4839.77 & 238.39 & 8.76 & 20.59 & 783.85 & 29.35 \\
\hline Alaska pollack & 3577.11 & 38.39 & 4.17 & 9.54 & 818.92 & 13.71 \\
\hline Herring & 4985.97 & 312.73 & 24.60 & 26.70 & 566.76 & 51.30 \\
\hline Tuna & 4406.66 & 235.48 & 16.40 & 56.07 & 605.00 & 72.47 \\
\hline Codfish & 3763.39 & 30.75 & 2.94 & 5.51 & 817.39 & 8.44 \\
\hline Mackerel & 5787.33 & 392.13 & 25.35 & 39.55 & 525.09 & 64.90 \\
\hline \multicolumn{7}{|c|}{ Fish: aquaculture production } \\
\hline Salmon & 5113.64 & 363.51 & 23.53 & 35.44 & 596.69 & 58.97 \\
\hline Trout & 4968.15 & 214.01 & 13.46 & 28.95 & 758.47 & 42.41 \\
\hline Carp & 4768.46 & 115.57 & 5.44 & 5.41 & 667.96 & 10.85 \\
\hline Pangasius & 6165.58 & 227.34 & 0.81 & 3.10 & 842.44 & 3.91 \\
\hline Tilapia & 3915.50 & 122.88 & 0.65 & 3.04 & 670.52 & 3.69 \\
\hline
\end{tabular}


Fig. 3 Global warming potential according to IPCC 2013 in $g$

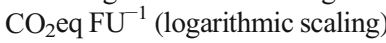

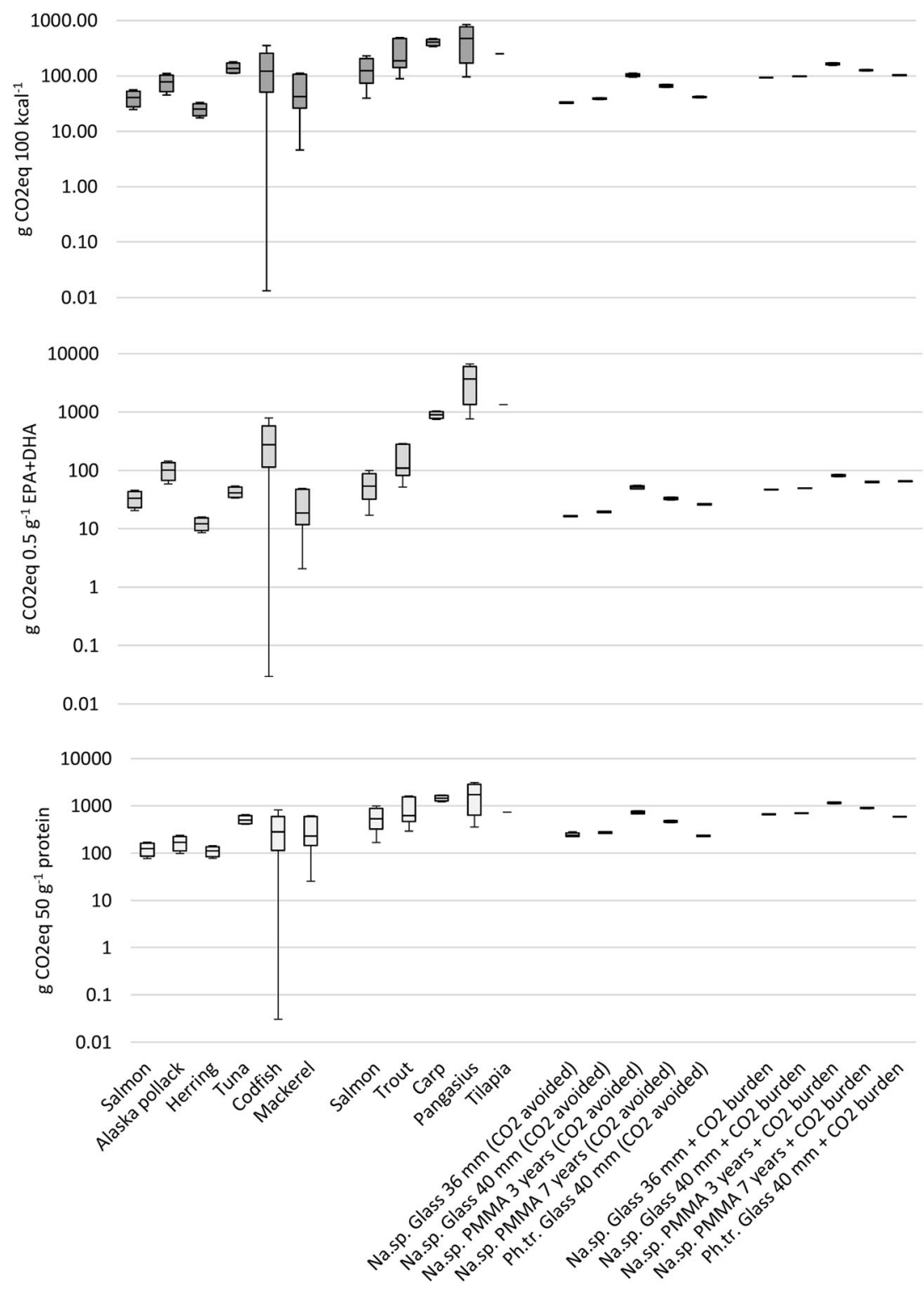

peak of over $3711 \mathrm{~g} \mathrm{CO}_{2}$ eq $0.5 \mathrm{~g}^{-1} \mathrm{EPA}+\mathrm{DHA}$ (see supplementary material), which makes it an unfavorable option as a source for these nutrients. Fish fillet production caused greenhouse gas (GHG) emissions from 25 to $471 \mathrm{~g}$ $100 \mathrm{kcal}^{-1}$, with capture production having its highest median at $135 \mathrm{~g} \mathrm{CO}_{2}$ eq $100 \mathrm{kcal}^{-1}$ and aquaculture production having a peak at $471 \mathrm{~g} \mathrm{CO}_{2}$ eq $100 \mathrm{kcal}^{-1}$. The microalgae scenarios with avoided $\mathrm{CO}_{2}$ burden caused $\mathrm{GHG}$ emissions from $33 \mathrm{~g}$ $100 \mathrm{kcal}^{-1}$ for the $36 \mathrm{~mm}$ borosilicate glass scenario to $103 \mathrm{~g}$ $100 \mathrm{kcal}^{-1}$ for the 3-year PMMA scenario. When accounting for the burden of $\mathrm{CO}_{2}$ production, scenarios showed emis-

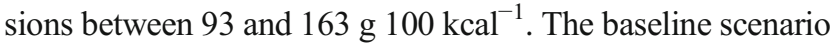
(Na.sp., glass, $40 \mathrm{~mm}$ ) with the burden of $\mathrm{CO}_{2}$ had approximately the same amount of GHG emissions per $100 \mathrm{kcal}$ as the worst scenario with avoided $\mathrm{CO}_{2}$ burden (Na.sp., PMMA, 3 years). Concerning the nutritional energy values, all borosilicate glass scenarios with avoided $\mathrm{CO}_{2}$ burden had lower GHG emissions than capture and aquaculture fish production (except wild-caught herring). Even though microalgae scenarios with the included burden of $\mathrm{CO}_{2}$ had higher GHG emissions than those without, the borosilicate glass scenarios of this category still outperformed all aquaculture fish per $100 \mathrm{kcal}$.

With regard to EPA+DHA, the microalgae borosilicate glass scenarios with avoided $\mathrm{CO}_{2}$ burden (16-26 $\mathrm{g} \mathrm{CO}_{2} \mathrm{eq}$ $0.5 \mathrm{~g}^{-1}$ EPA+DHA) were responsible for lower GHG emissions than the median values of all fish scenarios (33-3711 g $\mathrm{CO}_{2}$ eq $0.5 \mathrm{~g}^{-1}$ EPA+DHA), except herring and mackerel. Again, even the microalgae scenario with the highest GHG emissions (3-year PMMA with $\mathrm{CO}_{2}$ burden, $82 \mathrm{~g} \mathrm{CO}_{2}$ eq $0.5 \mathrm{~g}^{-1} \mathrm{EPA}+\mathrm{DHA}$ ) was preferable over most of the aquaculture fish production cases (median, $109-3710 \mathrm{~g} \mathrm{CO}_{2} \mathrm{eq} 0.5 \mathrm{~g}^{-1}$ 
EPA+DHA) except salmon (54 g CO 2 eq $0.5 \mathrm{~g}^{-1} \mathrm{EPA}+\mathrm{DHA}$ ). However, compared with capture production, the scenarios including PMMA as the reactor material were rather unfavorable, similar to the scenarios with the included burden of $\mathrm{CO}_{2}$, which were only able to compete with Alaska pollack.

Regarding protein, borosilicate glass scenarios with avoided $\mathrm{CO}_{2}$ burden (234-272 $\mathrm{g} \mathrm{CO}_{2}$ eq $50 \mathrm{~g}^{-1}$ protein) showed similar or higher emissions than those for capture production (111-283 $\mathrm{g} \mathrm{CO}_{2} \mathrm{eq} 50 \mathrm{~g}^{-1}$ protein). Only wildcaught tuna caused higher GHG emissions, with a median value of $493 \mathrm{~g} \mathrm{CO}_{2}$ eq $50 \mathrm{~g}^{-1}$ protein. Considering the median GHG emissions of aquaculture production (529-1725 g $50 \mathrm{~g}^{-1}$ protein), all microalgae scenarios with avoided $\mathrm{CO}_{2}$ burden showed similar or lower GHG emissions. In general, all microalgae scenarios caused similar or lower GHG emissions than those of aquaculture fish fillet production. Microalgae scenarios with the burden of $\mathrm{CO}_{2}$ had GHG emis-

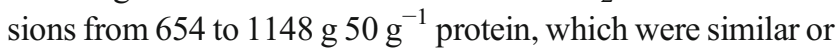
lower than those in aquaculture fish production. In comparison with capture fish fillet production, only the microalgae borosilicate glass scenarios with avoided $\mathrm{CO}_{2}$ burden were able to compete.

Wild-caught herring was the only fish that outperformed even the most favorable microalgae scenarios in all FUs. Concerning protein, wild-caught salmon and Alaska pollack also had lower GHG emissions than all microalgae scenarios. For both the fish and microalgae scenarios, the highest values were obtained in relation to the daily protein intake of $50 \mathrm{~g}$. Most GHG emissions from fish arose from feed production for aquaculture, and diesel usage for boats in the case of capture production. GHG emissions in microalgae cultivation were mostly due to energy-intensive processes that were carried out using nonrenewable energy sources. Additionally, the values showed that the production burden of $\mathrm{CO}_{2}$ added a significant amount of GHG emissions to the microalgae scenarios. On average, this burden caused GHG emissions of the microalgae scenarios to double per FU.

\section{Acidification}

In terms of the acidification potential of fish products (Fig. 4), the distribution is rather heterogeneous across the different species and production methods for all FUs. Concerning nutritional energy, both the lowest and highest emissions result from fish products originating from aquaculture production. Carp from aquaculture production had the lowest $\mathrm{SO}_{2}$ eq emissions of $0.00002 \mathrm{~g} \mathrm{SO}_{2}$ eq $100 \mathrm{kcal}^{-1}$, while tilapia from aquaculture had a value of $3.5 \mathrm{~g} \mathrm{SO}_{2}$ eq $100 \mathrm{kcal}^{-1}$. Nevertheless, wild-caught herring showed a low median emission value of $0.00009 \mathrm{~g} \mathrm{SO}_{2}$ eq $100 \mathrm{kcal}^{-1}$. All microalgae scenarios had a lower acidification potential than most fish, except herring and cod from capture production and carp from aquaculture. The microalgae borosilicate glass scenarios with avoided $\mathrm{CO}_{2}$ burden were responsible for $0.08-0.11 \mathrm{~g} \mathrm{SO}_{2} \mathrm{eq} 100 \mathrm{kcal}^{-1}$, whereas the PMMA scenarios with avoided $\mathrm{CO}_{2}$ burden had more than twofold higher emissions, with a range from $0.21-$ $0.36 \mathrm{~g} \mathrm{SO}_{2}$ eq $100 \mathrm{kcal}^{-1}$. Microalgae cultivation with the burden of $\mathrm{CO}_{2}$ production had emissions values ranging from $0.18-0.21 \mathrm{~g} \mathrm{SO}_{2}$ eq $100 \mathrm{kcal}^{-1}$ for the borosilicate glass scenarios and from 0.31-0.46 $\mathrm{g} \mathrm{SO}_{2}$ eq $100 \mathrm{kcal}^{-1}$ for the PMMA scenarios.

Considering the daily intake recommendation of EPA+ DHA, the distribution of values for microalgae and fish scenarios was similar. The $\mathrm{SO}_{2}$ eq emissions of fish production ranged from 0.00003-18.4 $\mathrm{g} \mathrm{SO}_{2}$ eq $0.5 \mathrm{~g}^{-1}$ EPA+DHA. Microalgae with avoided $\mathrm{CO}_{2}$ burden had emissions of 0.04-0.07 $\mathrm{g} \mathrm{SO}_{2}$ eq $0.5 \mathrm{~g}^{-1}$ EPA+DHA for the borosilicate glass scenarios and $0.10-0.18 \mathrm{~g} \mathrm{SO}_{2}$ eq $0.5 \mathrm{~g}^{-1}$ EPA+DHA for the PMMA scenarios, which indicates that even the acrylic glass scenarios performed better than most fish production scenarios. Microalgae with the burden of $\mathrm{CO}_{2}$ had an acidification potential ranging from $0.09-0.14 \mathrm{~g} \mathrm{SO}_{2}$ eq $0.5 \mathrm{~g}^{-1}$ $\mathrm{EPA}+\mathrm{DHA}$ for the borosilicate glass scenarios and 0.16 $0.23 \mathrm{~g} \mathrm{SO}_{2}$ eq $0.5 \mathrm{~g}^{-1}$ EPA+DHA for the PMMA scenarios. Even the microalgae scenarios with the burden of $\mathrm{CO}_{2}$ production could compete with most wild-caught and aquaculture fish species (exceptions: herring, codfish, mackerel, and carp). Similar to the global warming potential, the protein requirement on average also caused the highest acidification potential compared with the other FUs. The acidification potential of fish production ranged from $0.00006-10.1 \mathrm{~g} \mathrm{SO}_{2}$ eq $50 \mathrm{~g}^{-1}$ protein. Wild-caught herring and codfish as well as carp from aquaculture again outperformed all microalgae scenarios,

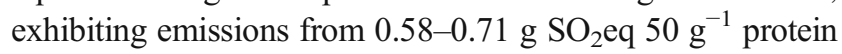
for glass scenarios with avoided $\mathrm{CO}_{2}$ burden and $1.48-2.52 \mathrm{~g}$ $\mathrm{SO}_{2}$ eq $50 \mathrm{~g}^{-1}$ protein for acrylic glass scenarios with avoided $\mathrm{CO}_{2}$ burden. Microalgae cultivation with the burden of $\mathrm{CO}_{2}$ had emissions ranging from $1.21-1.41 \mathrm{~g} \mathrm{SO}_{2} \mathrm{eq}_{50 \mathrm{~g}^{-1}}$ protein for the borosilicate glass scenarios and 2.21-3.25 $\mathrm{g} \mathrm{SO}_{2} \mathrm{eq}$ $50 \mathrm{~g}^{-1}$ protein for the PMMA scenarios. Moreover, Pangasius from aquaculture had a lower acidification potential than the 3-year PMMA scenario with avoided $\mathrm{CO}_{2}$ burden and the PMMA scenarios with the burden of $\mathrm{CO}_{2}$. Apart from PMMA being responsible for acidification, other critical points for $\mathrm{SO}_{2}$ eq emissions during microalgae cultivation comprised electricity use from nonrenewable resources, hydrogen peroxide use, and the utilization of ammonium fertilizer. $\mathrm{CO}_{2}$ production also resulted in a significantly higher acidification potential and approximately doubled the emissions of $\mathrm{SO}_{2}$ eq per FU. Concerning the fish scenarios, different hotspots were responsible for the heterogeneous distribution of values. In capture production, the major contributors were vessel operations and diesel. Bottom trawlers generated higher emissions through accelerated fuel use and cooling agent leakage than purse seine capture, which overall had hotspots regarding ice production and anti-fouling paint for 
Fig. 4 Acidification potential according to the CML-IA Baseline in $\mathrm{g} \mathrm{SO}_{2}$ eq $\mathrm{FU}^{-1}$ (logarithmic scaling)
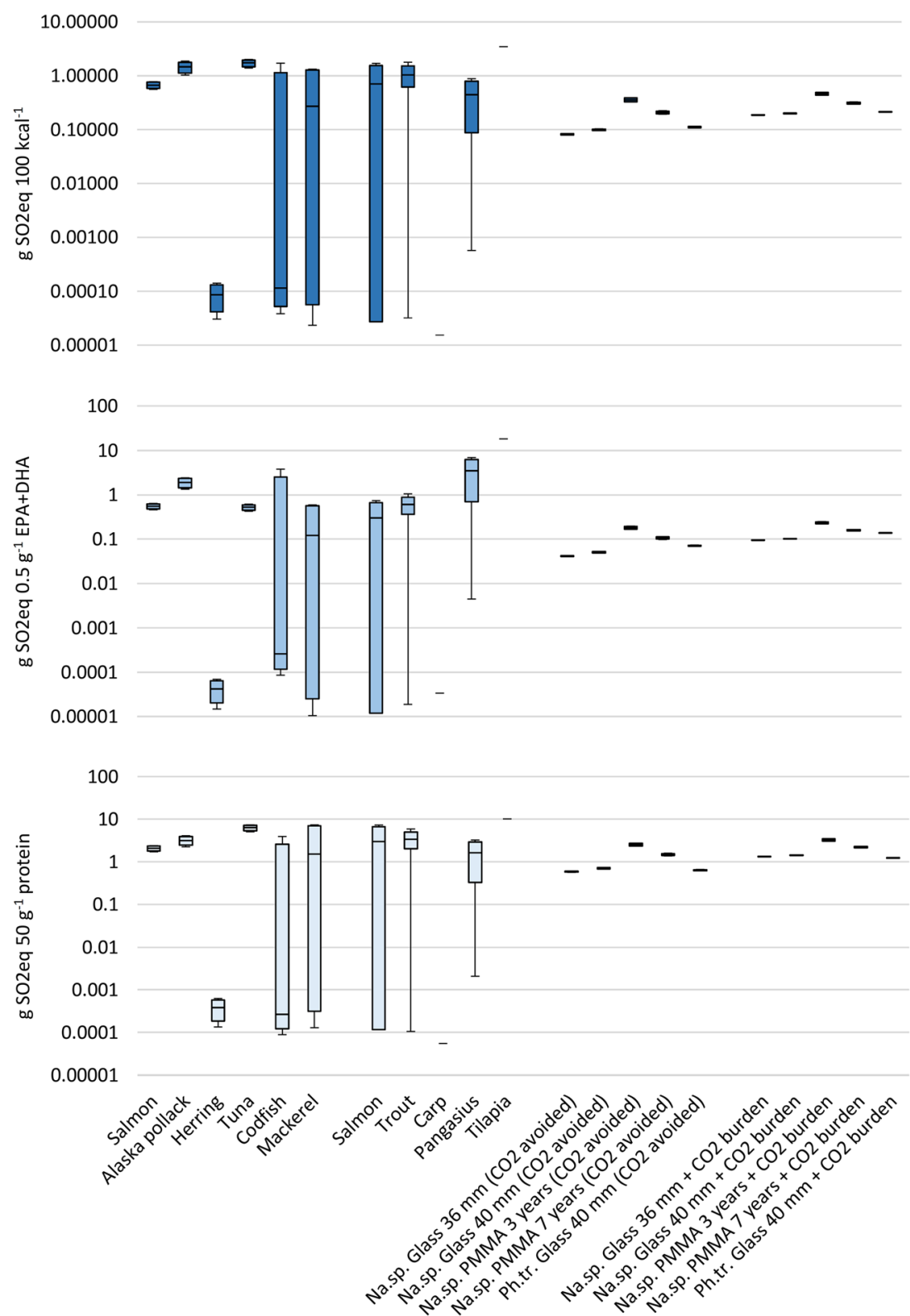

boats (Vázquez-Rowe et al. 2010; Cavadas et al. 2013). In aquaculture production, feed poses the highest threat in regard to $\mathrm{SO}_{2}$ eq emissions (d'Orbcastel et al. 2009; Cavadas et al. 2013), but electricity for recirculation for certain systems is also critical (Dekamin et al. 2015).

\section{Eutrophication}

The highest eutrophication potential (Fig. 5) was observed for aquaculture production. Concerning the nutritional value, fish scenarios emitted $0.00001-4.6 \mathrm{~g} \mathrm{PO}_{4}^{-}$eq $100 \mathrm{kcal}^{-1}$. In particular, salmon, trout, and Pangasius, which all derived from aquaculture, exhibited great emissions here. Microalgae with avoided $\mathrm{CO}_{2}$ burden were responsible for $0.19-0.23 \mathrm{~g} \mathrm{PO}_{4}{ }^{-} \mathrm{eq}$ $100 \mathrm{kcal}^{-1}$ and thus were only favorable over aquaculture fish production (except tilapia) and wild-caught tuna. Microalgae with the burden of $\mathrm{CO}_{2}$ production emitted $0.25-0.28 \mathrm{~g}$ $\mathrm{PO}_{4}{ }^{-}$eq $100 \mathrm{kcal}^{-1}$ and could compete well with aquaculture fish, except tilapia. Moreover, the borosilicate glass scenarios performed only slightly better than the PMMA scenarios.

In terms of EPA+DHA, the eutrophication potential of the fish scenarios had an extreme range between $0.000006 \mathrm{~g}$ $\mathrm{PO}_{4}{ }^{-}$eq $0.5 \mathrm{~g}^{-1}$ EPA+DHA for wild-caught herring and $14.9 \mathrm{~g} \mathrm{PO}_{4}^{-}$eq $0.5 \mathrm{~g}^{-1}$ EPA+DHA for pangasius from aquaculture. The microalgae scenarios with avoided $\mathrm{CO}_{2}$ caused similar or slightly higher $\mathrm{PO}_{4}{ }^{-}$eq emissions than capture production but were overall favorable over aquaculture production. Microalgae scenarios with avoided $\mathrm{CO}_{2}$ burden had a eutrophication potential ranging from $0.09-0.13 \mathrm{~g} \mathrm{PO}_{4}{ }^{-} \mathrm{eq}$ $0.5 \mathrm{~g}^{-1}$ EPA+DHA. Microalgae scenarios with the burden of 
Fig. 5 Eutrophication potential according to the CML-IA

Baseline in $\mathrm{g} \mathrm{PO}_{4}^{-}$eq $\mathrm{FU}^{-1}$ (logarithmic scaling)
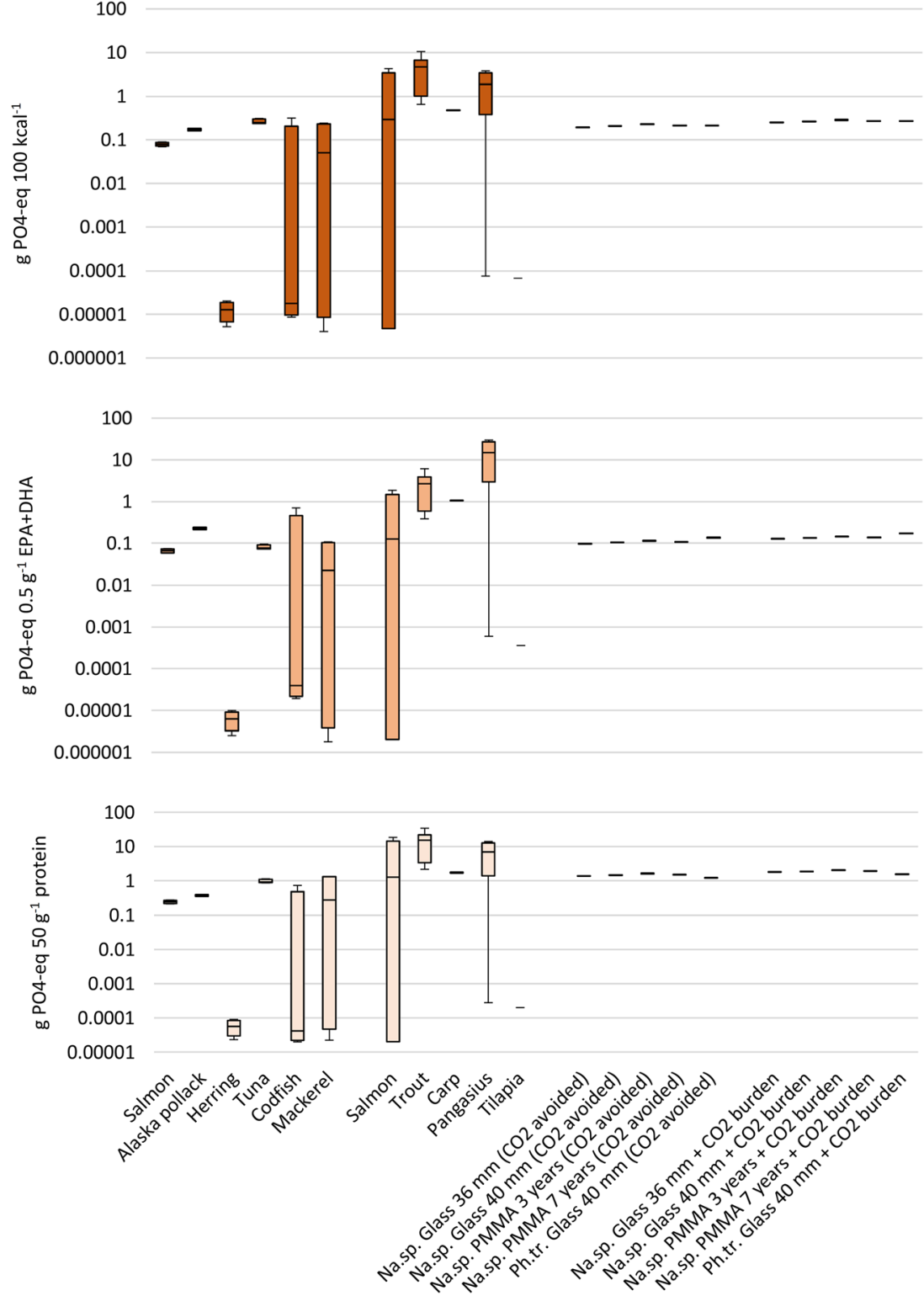

$\mathrm{CO}_{2}$ production had emissions ranging from $0.12-0.17 \mathrm{~g}$ $\mathrm{PO}_{4}^{-}$eq $0.5 \mathrm{~g}^{-1}$ EPA+DHA whereas here the alternative microalgae species scenario with $P$. tricornutum caused the highest emissions. In contrast, the $P$. tricornutum scenario was most favorable in terms of protein, with $1.20 \mathrm{~g} \mathrm{PO}_{4}^{-}$eq $50 \mathrm{~g}^{-1}$ protein for avoided $\mathrm{CO}_{2}$, whereas the 3-year PMMA scenario with the burden of $\mathrm{CO}_{2}$ was responsible for $2.01 \mathrm{~g} \mathrm{PO}_{4}{ }^{-} \mathrm{eq}$ $50 \mathrm{~g}^{-1}$ protein. Microalgae with the avoided burden of $\mathrm{CO}_{2}$ were thus again preferable over aquaculture production (except tilapia) but inferior to capture production. When the burden of $\mathrm{CO}_{2}$ production during microalgae cultivation was accounted for, scenarios had eutrophication potentials similar to those of aquaculture fish production and still lower emissions than with trout and Pangasius. Overall, the eutrophication potential of fish products in terms of protein reached values ranging from $0.00004-15.1 \mathrm{~g} \mathrm{PO}_{4}^{-}$eq $50 \mathrm{~g}^{-1}$ protein.
Similar to the situation for other emissions, feed production for aquaculture fish generated the highest share of $\mathrm{PO}_{4}{ }^{-} \mathrm{eq}$ emissions (Bosma et al. 2009), although on-farm emissions, mainly due to nutrient emissions, were also a critical point (Chen et al. 2015; Dekamin et al. 2015; Biermann and Geist 2019). In capture production, vessel operations were a hotspot (Vázquez-Rowe et al. 2010; Ramos et al. 2011), as was diesel, which is especially critical in capture by fuel-intensive fleets (Cavadas et al. 2013).

\section{Cumulative energy demand}

The distribution of the cumulative energy demand (CED) (Fig. 6) is also fairly heterogeneous for all FUs and no clear trend is visible concerning a potentially better performance of any fish production method. In terms of nutritional value, 
Fig. $6 \mathrm{CED}$ in $\mathrm{MJ} \mathrm{FU}^{-1}$ (logarithmic scaling)

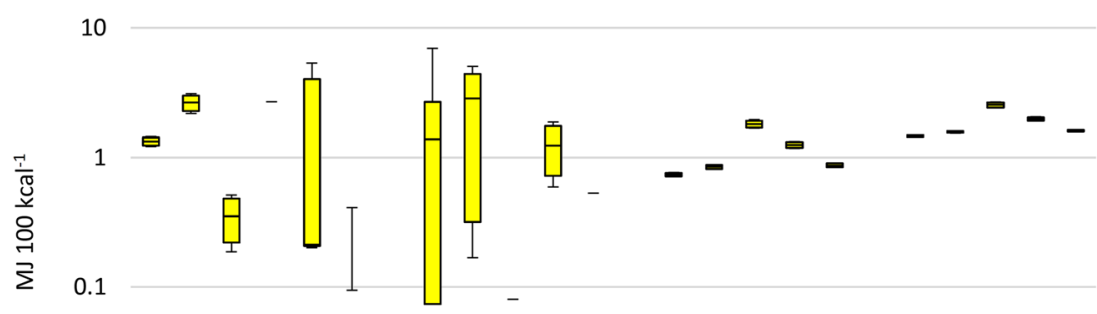

0.01

100

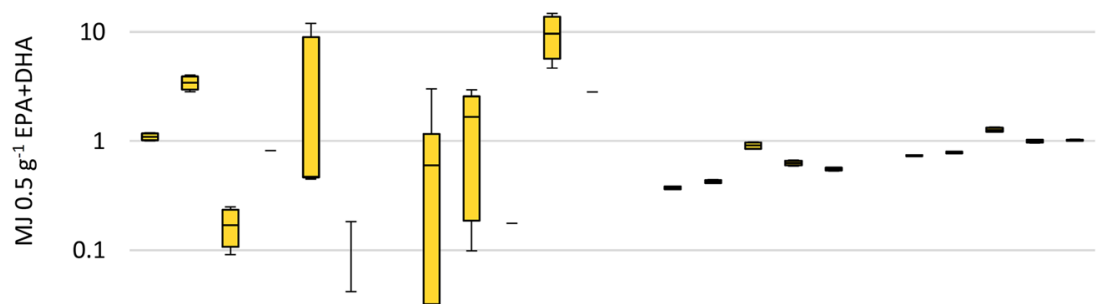

0.01

100

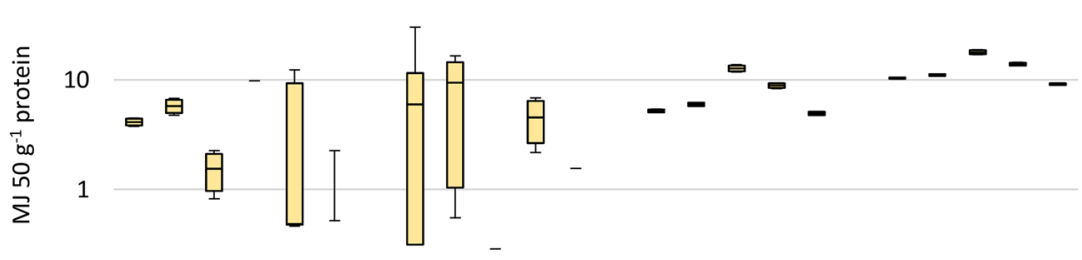

0.1

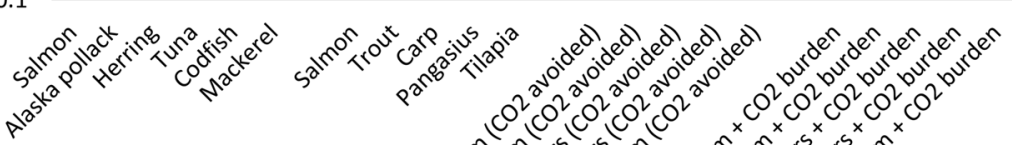

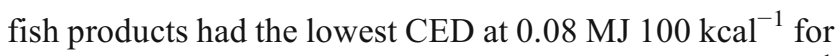
carp from aquaculture and the highest at $2.85 \mathrm{MJ}^{100 \mathrm{kcal}^{-1}}$ for trout from aquaculture. For the microalgae scenarios with avoided $\mathrm{CO}_{2}$ burden, the borosilicate glass scenarios were favorable over the PMMA scenarios, with a range of 0.74 $0.87 \mathrm{MJ} 100 \mathrm{kcal}^{-1}$ for glass and 1.25-1.80 MJ $100 \mathrm{kcal}^{-1}$ for PMMA. When $\mathrm{CO}_{2}$ production was accounted for, the glass scenarios used 1.46-1.60 MJ $100 \mathrm{kcal}^{-1}$ and PMMA scenarios used 1.98-2.53 MJ $100 \mathrm{kcal}^{-1}$. Accordingly, the energy use of microalgae cultivation is comparable with the energy demand of fish production. The same can be observed concerning the EPA+DHA content. No general statement can be made regarding whether microalgae perform better than certain fish production methods. Microalgae with avoided $\mathrm{CO}_{2}$ burden consumed $0.37-0.55 \mathrm{MJ} 0.5 \mathrm{~g}^{-1} \mathrm{EPA}+$ DHA for glass and 0.63-0.91 MJ $0.5 \mathrm{~g}_{-1}$ EPA+DHA for PMMA whereas microalgae with the burden of $\mathrm{CO}_{2}$ production used 0.73-1.02 MJ $0.5 \mathrm{~g}^{-1} \mathrm{EPA}+\mathrm{DHA}$ for glass and 0.99-1.27 MJ 0.5 $\mathrm{g}^{-1}$ EPA+DHA for PMMA. The energy demand of fish products ranged between $0.04 \mathrm{MJ} 0.5 \mathrm{~g}^{-1}$ $\mathrm{EPA}+\mathrm{DHA}$ for wild-caught mackerel and 9.69 MJ $0.5 \mathrm{~g}^{-1}$ EPA+DHA for pangasius from aquaculture production. Again, all scenarios showed the highest values concerning protein content. The microalgae borosilicate glass scenarios with avoided $\mathrm{CO}_{2}$ burden (4.92-5.95 MJ $50 \mathrm{~g}^{-1}$ protein) corresponded to the average values of fish production (0.29-9.76 MJ $50 \mathrm{~g}^{-1}$ protein). However, the PMMA scenarios on average had a higher energy demand (8.76- 


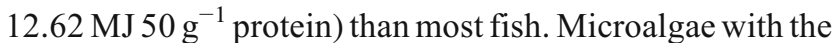
full burden of $\mathrm{CO}_{2}$ production used 9.07-17.78 MJ $50 \mathrm{~g}^{-1}$ protein, which exceeded all fish scenarios, except that $P$. tricornutum used slightly less energy than herring and trout. Whereas the energy demand for microalgae cultivation again predominantly arose from energy-intensive processes and PMMA, the CED of fish was mainly due to the exact method of capture and aquaculture production. Thus, demersal fisheries were described to use more fuel than pelagic fisheries, representing the main contributor in capture production (Ziegler et al. 2012). In aquaculture production, feed is generally the highest consumer of energy, more precisely, the milling of feed, although the energy for this process is also highly dependent on the energy source used (Pelletier et al. 2009). Further critical processes here were on-farm electricity use for pumps, aeration, water treatment, etc., during the farming and hatchery stages (Smárason et al. 2017).

\section{Water scarcity}

The usage of blue water in fish production is only relevant for aquaculture, where the largest share of blue water arises from irrigation during crop cultivation (especially rice) for feed, while the remaining consumption is largely due to rearing production (Mungkung et al. 2013; Hognes et al. 2014). However, even for aquaculture fish production, the water use was not consequently assessed, which is why values were presented as a range across all analyzed fish species. Compared with fish production in aquaculture, microalgae consumed far less blue water (Fig. 7). Based on the nutritional energy value, aquaculture fish production

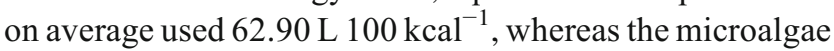
scenarios with avoided $\mathrm{CO}_{2}$ burden only needed $0.95-$ $1.30 \mathrm{~L} 100 \mathrm{kcal}^{-1}$, and those with the full burden of $\mathrm{CO}_{2}$ needed 1.26-1.61 L $100 \mathrm{kcal}^{-1}$. Even though the PMMA scenarios were the least favorable, their water use was only marginally higher than that in the borosilicate glass scenarios. With regard to EPA+DHA, microalgae had a water

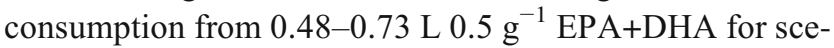
narios with avoided $\mathrm{CO}_{2}$ burden and $0.63-0.93 \mathrm{~L}_{0.5} \mathrm{~g}^{-1}$ $\mathrm{EPA}+\mathrm{DHA}$ for scenarios with the burden of $\mathrm{CO}_{2}$ production. Aquaculture fish used an amount that was more than 50-fold higher, with the average at $47.01{\mathrm{~L} 0.5 \mathrm{~g}^{-1} \mathrm{EPA}+}^{-}$ DHA. The highest values for both microalgae and fish were again reached for protein. Aquaculture fish consumed

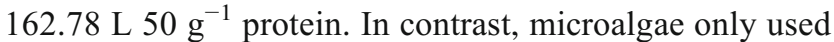

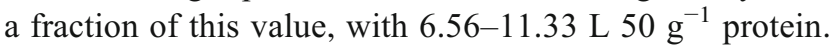
$P$. tricornutum with avoided $\mathrm{CO}_{2}$ burden was the most favorable scenario, which can be traced back to its protein content being higher than that of Nannochloropsis sp. as used in the other scenarios.

\section{Land use}

Concerning the land use of fish products (Fig. 8), values for both aquaculture and capture production were available. As the land use values of microalgae were directly analyzed from the life cycle inventory, scenarios with the burden of $\mathrm{CO}_{2}$ did not differ from those with avoided $\mathrm{CO}_{2}$ burden. Consequently, these scenarios were not presented separately. The land use of capture production was clearly lower than the values for aquaculture fish and equal to the values for microalgae. Where capture production had a land use rate of $0.04 \mathrm{~m}^{2}\left(100 \mathrm{kcal}^{-1}\right.$ (probably resulting from refineries and pipelines for diesel production), aquaculture production needed an approximately fourfold higher amount, at $0.16 \mathrm{~m}^{2}$ $(100 \mathrm{kcal})^{-1}$. In contrast, microalgae only presented values from $0.004-0.0046 \mathrm{~m}^{2} 100 \mathrm{kcal}^{-1}$. Similar trends can be observed for the remaining FUs. Concerning EPA+DHA, fish showed average values of 0.03 to $0.12 \mathrm{~m}^{2} 0.5 \mathrm{~g}^{-1} \mathrm{EPA}+\mathrm{DHA}$ for capture and aquaculture production, respectively. Microalgae land use values in terms of EPA+DHA ranged from 0.002 to $0.0028 \mathrm{~m}^{2} 0.5 \mathrm{~g}^{-1} \mathrm{EPA}+\mathrm{DHA}$. The daily recommendation of protein again was characterized by the highest values for all scenarios, ranging from 0.025 $0.032 \mathrm{~m}^{2} 50 \mathrm{~g}^{-1}$ protein, whereas $P$. tricornutum again was the most favorable scenario here. Fish used $0.11-0.42 \mathrm{~m}^{2}$ $50 \mathrm{~g}^{-1}$ protein. Even the unfavorable microalgae scenarios outperformed fish production in all FUs. Concerning aquaculture, feed production is clearly the dominant factor in the high land use rates (Mungkung et al. 2013; Seves et al. 2016). No explanation could be obtained from the literature on where the land use of capture fish production comes from. Microalgae had a relatively low land use rate due to the vertical dimension of the reactor and the relatively high yields of microalgae. As an additional advantage, the photobioreactor (PBR) was built on non-arable land.

\section{Discussion}

Our analysis compared the environmental impacts of the cultivation of microalgae for human consumption with the impacts of fish products. We applied different functional units representing key nutrients (DM, kcal, EPA+DHA, protein) in these edibles. Simultaneously, we analyzed to what extent the modeling of $\mathrm{CO}_{2}$ either as an avoided burden or with its full burden of production impacted the results. It was shown that microalgae production was a feasible option for fish fillets as a source of EPA+DHA and protein. The microalgae scenarios with avoided $\mathrm{CO}_{2}$ mostly had similar or less environmental impacts than capture fish production and always far lower impacts than aquaculture fish production. When accounting for the full burden of $\mathrm{CO}_{2}$ production, the environmental impacts increased for all indicators, and approximately doubled 
Fig. 7 Blue water use in $\mathrm{L} \mathrm{FU}^{-1}$ (logarithmic scaling)
1000

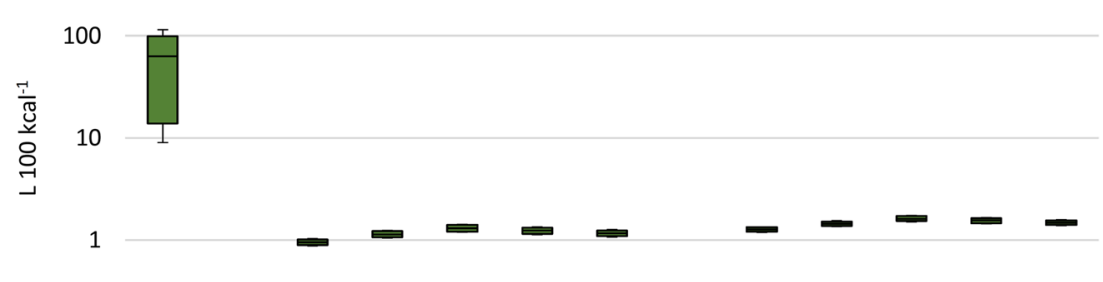

$$
0.1
$$

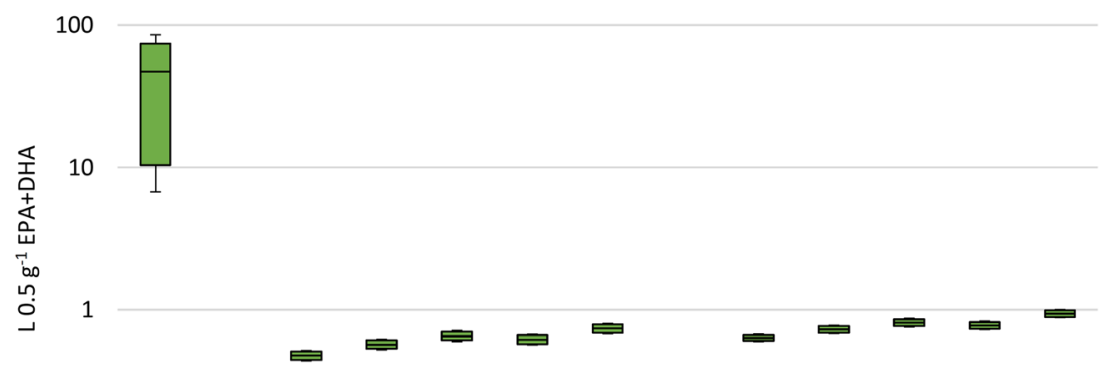

0.1

1000
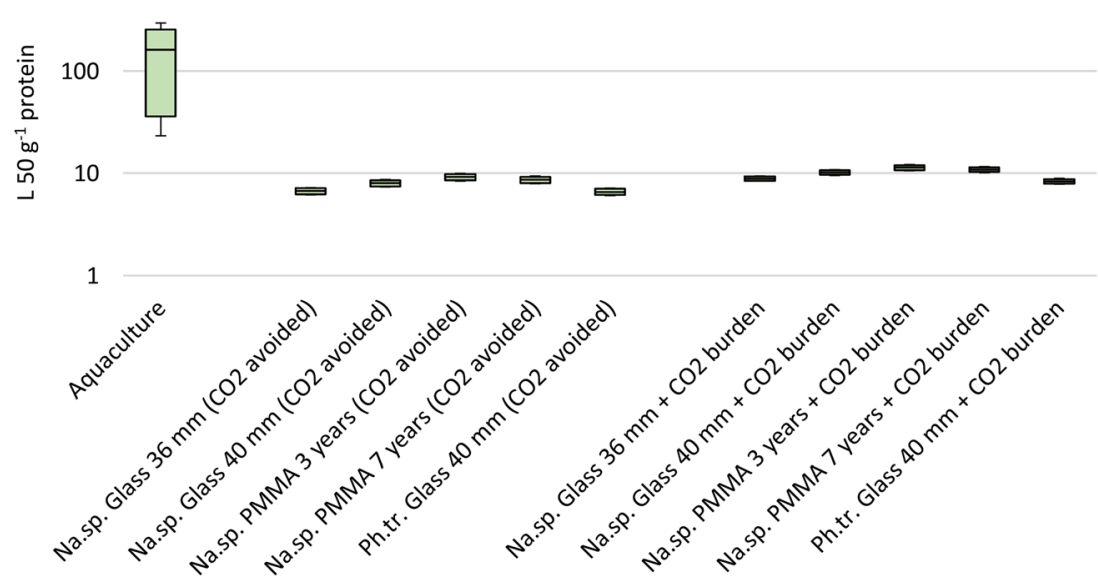

the impacts of the global warming potential, acidification potential, and CED. However, the scenarios with included $\mathrm{CO}_{2}$ burden still had similar or lower environmental impacts than aquaculture fish. In particular, popular fish species such as Alaska pollack, aquaculture salmon, and pangasius were mostly highly unfavorable in terms of their environmental impacts.

Aquaculture only had a small share of total inland fish production in Germany of approximately 13\% in 2017 (FAO 2019b) (Fig. S11). However, with the degree of selfsufficiency amounting to $26.5 \%$ according to the German Federal Ministry of Food and Agriculture (BMEL 2019) and taking into account the most consumed fish species in Germany (see chapter 2.3 Systematic literature research: fish consumption in Germany), it can be supposed that the total amount of fish consumed originates equally from capture and aquaculture production. Concerning the world average, fish are almost equally produced from wild capture and aquaculture, with the latter having a share of approximately $47 \%$ (FAO 2018). The greatest environmental burden of aquaculture fish fillet production can be traced back to land use due to feed production. Feed crops for aquaculture fish use far more land and have a lower productivity than microalgae from PBR. Moreover, microalgae can be cultivated on infertile land, which makes them economically favorable over aquaculture fish.

The per capita consumption of fish in Germany amounted to $13.8 \mathrm{~kg} \mathrm{year}{ }^{-1}$ in 2018 (BMEL 2019). Assuming an 
Fig. 8 Land use in $\mathrm{m}^{2} \mathrm{FU}^{-1}$ (logarithmic scaling)
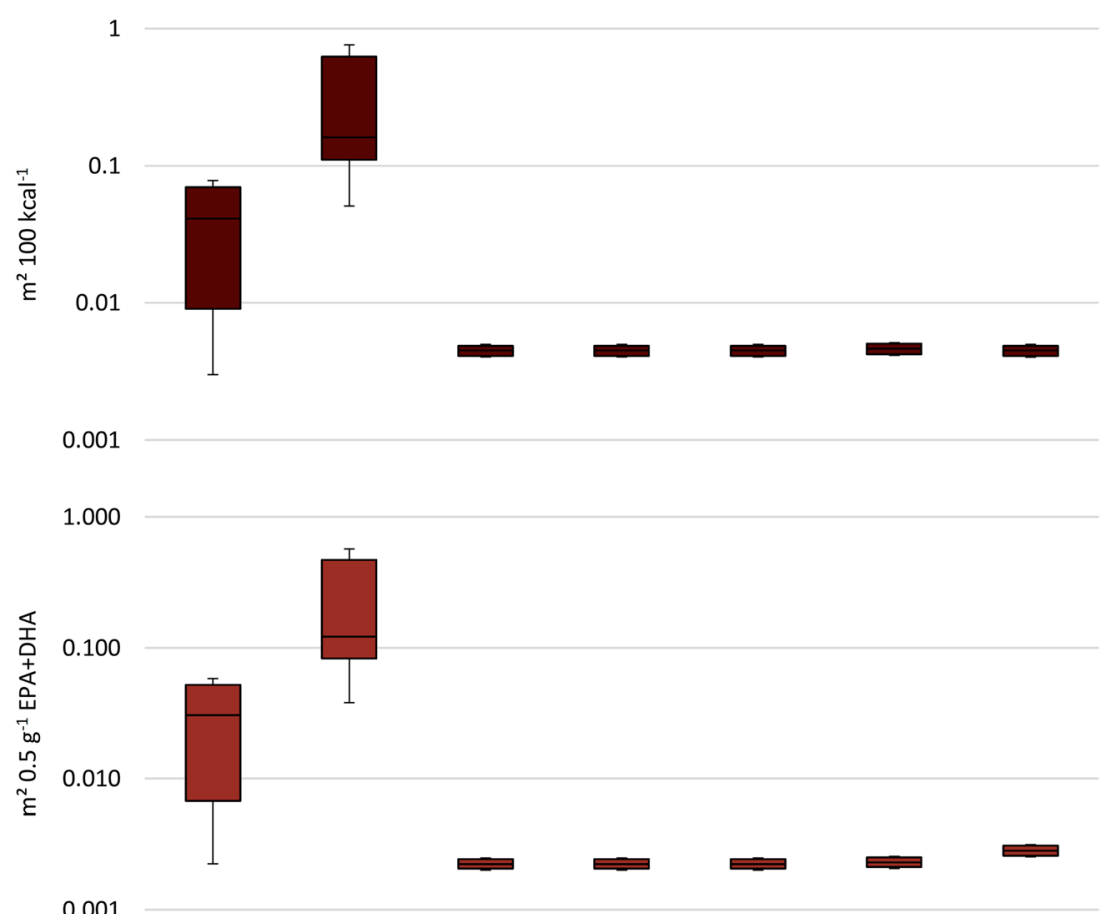

10.000

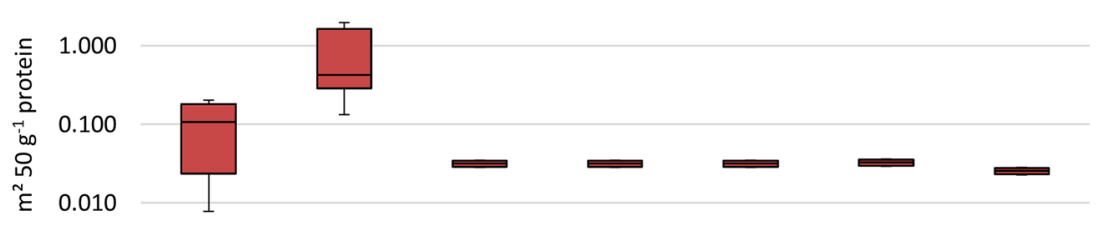

0.001

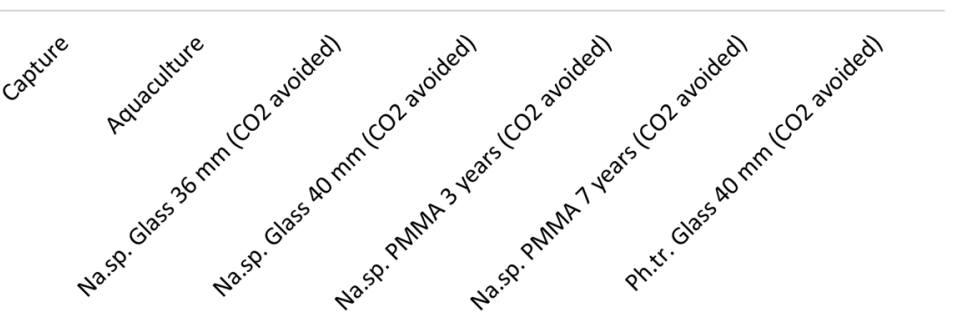

average EPA+DHA content of $6.69 \mathrm{~g} \mathrm{~kg}^{-1}$ fish (BMEL 2017), this would generate a per capita supply of approximately $0.25 \mathrm{~g} \mathrm{day}^{-1}$, which, according to the DGE (German Nutrition Society), is a sufficient daily supply to prevent diseases (German Nutrition Society 2016). However, higher amounts of 0.5-0.6 g EPA+DHA day ${ }^{-1}$ are also recommended in the literature in order to provide health benefits and actively reduce the risk for cardiovascular diseases (Harris 2007; EFSA Panel on Dietetic Products Nutrition and Allergies (NDA) 2012; Salem and Eggersdorfer 2015). If a supply gap of $0.25-0.35 \mathrm{~g} \mathrm{capita}^{-1}$ day $^{-1}$ is consequently presupposed, an additional amount of 7500-10,500 t EPA+ DHA year ${ }^{-1}$ would be required. To produce this amount from Nannochloropsis sp., 179,000-250,000 t year ${ }^{-1}$ dry biomass would be needed, which corresponds to approximately 3400-
4700 ha of PBR area. However, it would be necessary to consume approximately 6.0-8.4 g of Nannochloropsis sp. dry biomass per day in order to reach the recommended additional intake of $0.25-0.35 \mathrm{~g} \mathrm{day}^{-1}$. Consequently, microalgae as a source for EPA+DHA can probably not replace fish but would rather be an economically desirable complementation of fish.

There are some limitations that need to be addressed. Some variance occurred in the LCIA values for fish products (Tab. S2). System boundaries varied at times to a great extent, whereas it was not always clearly indicated in the literature what they comprised. Therefore, fish products were harmonized to the system boundary "at the farm gate," as there was the least uncertainty, and transport and freezing during transportation were added by means of our own calculations. 
Another factor concerning fish products was the use of a set of different LCIA methods, which might have influenced the final obtained LCIA values for fish to some extent. In the reviewed literature, the methods IPCC 2007, CML 2001, CML 2, CML-IA Baseline, CED, ILCD 2010, EDIP 2003, ReCiPe 2006, Ecological Scarcity 2006, and the Water footprint according to Aubin et al. (2009) were used. However, the IPCC and CML methods noticeably dominated the life cycle impact assessments and are similar in their methodological approach. For some fish species, only one to three scenarios were available. Finally, the exact capture and aquaculture conditions can drastically influence the environmental impact, which was not analyzed in this study. An analysis of the global warming potential of different capture and aquaculture methods can be accessed in the supplementary material (Figs. S7-S10). The consequent use of rather favorable options of fish production could thus put the comparison with microalgae in another perspective.

A further limitation of this work results from the fact that the analysis considered only the protein quantity but not the protein quality, where the latter depends on two factors: the amount of indispensable amino acids and the digestibility of the protein. Algae are generally regarded as valuable protein sources. Data show that their essential amino acid profiles largely meet the requirements recommended by the FAO (1991), Fleurence (1999), although lysine and tryptophan are often limiting amino acids in most algae species (Kolb et al. 1999; Dawczynski et al. 2007; Volkmann et al. 2008). It is important to note that the Nannochloropsis sp. and $P$. tricornutum, which we evaluated in the current work, were characterized by lysine and tryptophan concentrations comparable with those of Chlorella and Spirulina (Chacón-Lee and González-Mariño 2010; Templeton and Laurens 2015), with Spirulina being recommended by the WHO to feed malnourished children. The digestibility of microalgae has been estimated to range between 75 and 90\% (Bleakley and Hayes 2017).

Moreover, an environmental analysis of microalgae production concerning other nutrients would be worthwhile, e.g., vitamin $B_{12}$ and an investigation of amino acids. Likewise, the environmental impacts of other food groups, in particular protein sources (as microalgae and fish both showed the least favorable results in terms of protein), such as different meats and dairy products, could be compared with microalgae regarding the nutritional profile.

The detailed microalgae data obtained from this study can be used in other environmental assessments to compare the impact of microalgae or products made of microalgae with other products and product categories. The exact LCI and LCIA values were included per $\mathrm{kg}$ DM in the supplementary material, which should provide a good basis for further studies. Moreover, the LCIA categories used are relevant on a global scale.

\section{Conclusion}

Microalgae that are cultivated under conditions that avoid $\mathrm{CO} 2$ burden are a sustainable and valuable source of EPA, DHA, and high-quality proteins. These organisms can be produced with lower environmental impacts than fish from both capture and aquaculture production. Microalgae biomass cultivation that includes the burden of $\mathrm{CO}_{2}$ production still has similar or lower environmental impacts than aquaculture fish. Microalgae cultivation is sustainable in a "colder" temperate climate like that in Germany, and microalgae are definitely able to compete with fish as an alternative nutrient resource. Regarding the recommended daily intake of EPA and DHA, microalgae represent-from an environmental point of view-an advisable source of nutrients.

Acknowledgements Open Access funding provided by Projekt DEAL.

Funding information The study was funded by the Federal Ministry of Education and Research (grant no: 031B0366A).

\section{Compliance with ethical standards}

Conflict of interest The authors declare that they have no conflict of interest.

Open Access This article is licensed under a Creative Commons Attribution 4.0 International License, which permits use, sharing, adaptation, distribution and reproduction in any medium or format, as long as you give appropriate credit to the original author(s) and the source, provide a link to the Creative Commons licence, and indicate if changes were made. The images or other third party material in this article are included in the article's Creative Commons licence, unless indicated otherwise in a credit line to the material. If material is not included in the article's Creative Commons licence and your intended use is not permitted by statutory regulation or exceeds the permitted use, you will need to obtain permission directly from the copyright holder. To view a copy of this licence, visit http://creativecommons.org/licenses/by/4.0/.

\section{References}

Aubin J, Papatryphon E, van der Werf HMG, Chatzifotis S (2009) Assessment of the environmental impact of carnivorous finfish production systems using life cycle assessment. Journal of Cleaner Production 17(3):354-361

Batan L, Quinn JC, Bradley TH (2013) Analysis of water footprint of a photobioreactor microalgae biofuel production system from blue, green and lifecycle perspectives. Algal Res 2:196-203

Becker EW (2007) Microalgae as a source of protein. Biotechnol Adv 25: $207-210$

Biermann G, Geist J (2019) Life cycle assessment of common carp (Cyprinus carpio L.) - a comparison of the environmental impacts of conventional and organic carp aquaculture in Germany. Aquaculture 501:404-415

Bleakley S, Hayes M (2017) Algal proteins: extraction, application, and challenges concerning production. Foods 6:33 
BMEL (2017) Bundeslebensmittelschlüssel version 3.02. https://www. blsdb.de/. Accessed 7 May 2019

BMEL (2019) Statistiken und Berichte des BMEL. http://www.bmelstatistik.de/. Accessed 7 May 2019

Bosma RH, Hanh CTT, Potting J (2009) Environmental impact assessment of the pangasius sector in the Mekong Delta. Report. Wageningen University, Wageningen, Netherlands

Boyd CE, Polioudakis M, Hanson T (2011) Carbon footprint of US farmreared catfish. Report. Department of Fisheries and Allied Aquacultures, Auburn University, Auburn, Alabama, USA

de Bruijn H, van Duin R, Huijbregts MAJ (2002) Handbook on Life Cycle Assessment. Springer Netherlands, Dordrecht

Cavadas A, Teixeira A, Neto B, Rodrigues S (2013) Assessing the environmental impact of the fish and seafood consumption patterns in Portugal. Poster presented at 6th International Conference on Life Cycle Management. Gothenburg, Sweden

Chacón-Lee TL, González-Mariño GE (2010) Microalgae for "healthy" foods-possibilities and challenges. Compr Rev Food Sci Food Saf 9: 655-675

Chen X, Samson E, Tocqueville A, Aubin J (2015) Environmental assessment of trout farming in France by life cycle assessment: using bootstrapped principal component analysis to better define system classification. J Clean Prod 87:87-95

Clune S, Crossin E, Verghese K (2017) Systematic review of greenhouse gas emissions for different fresh food categories. J Clean Prod 140: 766-783

Collotta M, Champagne P, Mabee W, Tomasoni G (2018) Wastewater and waste $\mathrm{CO}_{2}$ for sustainable biofuels from microalgae. Algal Res 29:12-21

d'Orbcastel ER, Blancheton JP, Aubin J (2009) Towards environmentally sustainable aquaculture: comparison between two trout farming systems using Life Cycle Assessment. Aquac Eng 40:113-119

Dawczynski C, Schubert R, Jahreis G (2007) Amino acids, fatty acids, and dietary fibre in edible seaweed products. Food Chem 103:891899

Dekamin M, Veisi H, Safari E, Liaghati H, Khoshbakht K, Dekamin MG (2015) Life cycle assessment for rainbow trout (Oncorhynchus mykiss) production systems: a case study for Iran. J Clean Prod 91: $43-55$

EFSA Panel on Dietetic Products Nutrition and Allergies (NDA) (2012) Scientific opinion on the tolerable upper intake level of eicosapentaenoic acid (EPA), docosahexaenoic acid (DHA) and docosapentaenoic acid (DPA). EFSA J 10:1-48

Fábregas J, Maseda A, Domínguez A, Otero A (2004) The cell composition of Nannochloropsis sp. changes under different irradiances in semicontinuous culture. World J Microbiol Biotechnol 20:31-35

FAO (1991) Protein quality evaluation - report of joint FAO/WHO expert consultation. FAO, Rome

FAO (2018) The state of world fisheries and aquaculture 2018 - meeting the sustainable development goals. Rome

FAO (2019a) Fisheries and aquaculture resources. http://www.fao.org/ fishery/resources/en. Accessed 23 May 2019

FAO (2019b) Fishery and aquaculture country profiles: the Federal Republic of Germany. http://www.fao.org/fishery/facp/DEU/en. Accessed 17 July 2019

Fleurence J (1999) Seaweed proteins: biochemical, nutritional aspects and potential uses. Trends Food Sci Technol 10:25-28

Frischknecht R, Jungbluth N, Althaus H, Bauer C, Doka G, Dones R, Hischier R, Hellweg S, Humbert S, Köllner T, Loerincik Y, Margni $\mathrm{M}$, Nemecek T (2007) Implementation of life cycle impact assessment methods. Ecoinvent report no. 3, v2.0. Swiss Centre for Life Cycle Inventories. Dübendorf, $151 \mathrm{p}$

German Nutrition Society (2016) Regelmäßig Fisch auf den Tisch! https://www.dge.de/presse/pm/regelmaessig-fisch-auf-den-tisch/. Accessed 30 July 2019
Harris WS (2007) International recommendations for consumption of long-chain omega-3 fatty acids. J Cardiovasc Med 8:S50-S52

Hoekstra AY, Mekonnen MM, Chapagain AK, Mathews RE, Richter BD (2012) Global monthly water scarcity: blue water footprints versus blue water availability. PLoS One 7:e0032688

Hognes ES, Nilsson K, Sund V, Ziegler F (2014) LCA of Norwegian salmon production. Report. SINTEF Fisheries and Aquaculture, Trondheim, Norway

Hulatt CJ, Wijffels RH, Bolla S, Kiron V (2017) Production of fatty acids and protein by Nannochloropsis in flat-plate photobioreactors. PLoS One 12:e170440

IPCC (2014) Climate change 2014: synthesis report. Contribution of Working Groups I, II and III to the Fifth Assessment Report of the Intergovernmental Panel on Climate Change. IPCC, Geneva, Switzerland

Kadam KL (2001) Microalgae production from power plant flue gas: environmental implications on a life cycle basis. Contract:1-63. https://doi.org/10.2172/783405

Keller M (2019) Rangfolge der bedeutendsten See- und Süßwasserfische in Prozent. https://www.fischinfo.de/index.php/markt/92datenfakten/4946-marktanteile-2018. Accessed 7 May 2019

Keller H, Rettenmaier N, Schorb A, Dittrich M, Reinhardt GA, de Wolf P, van der Voort M, Spruijt J, Potters J, Elissen H, Stehr M, Reyer S, Lochmann D (2017) Integrated sustainability assessment of algaebased PUFA production. Report. IFEU - Institute for Energy and Environmental Research, Heidelberg

Kent M, Welladsen HM, Mangott A, Li Y (2015) Nutritional evaluation of Australian microalgae as potential human health supplements. PLoS One 10:e118985

Kolb N, Vallorani L, Stocchi V (1999) Chemical composition and evaluation of protein quality by amino acid score method of edible brown marine algae Arame (Eisenia bicyclis) and Hijiki (Hijikia fusiforme). Acta Aliment 28:213-222

Ma XN, Chen TP, Yang B, Liu J, Chen F (2016) Lipid production from Nannochloropsis. Mar Drugs 14:61

Meier T, Christen O (2012) Environmental impacts of dietary recommendations and dietary styles: Germany as an example. Environ Sci Technol 47:877-888

Molino A, Iovine A, Casella P, Mehariya S, Chianese S, Cerbone A, Rimauro J, Musmarra D (2018) Microalgae characterization for consolidated and new application in human food, animal feed and nutraceuticals. Int J Environ Res Public Health 15:2436

Mungkung R, Aubin J, Prihadi TH, Slembrouck J, Van Der Werf HMG, Legendre M (2013) Life cycle assessment for environmentally sustainable aquaculture management: a case study of combined aquaculture systems for carp and tilapia. J Clean Prod 57:249-256

Paes CRPS, Faria GR, Tinoco NAB, Castro DFJA, Barbarino E, Lourenco SO (2016) Growth, nutrient uptake and chemical composition of Chlorella sp. and Nannochloropsis oculata under nitrogen starvation. Lat Am J Aquat Res 44:275-292

Parodi A, Leip A, De Boer IJM, Slegers PM, Ziegler F, Temme EHM, Herrero M, Tuomisto H, Valin H, VanMiddelaar CE, VanLoon JJA, VanZanten HHE (2018) The potential of future foods for sustainable and healthy diets. Nat Sustain 1:782-789

Pelletier N, Tyedmers P, Sonesson U, Scholz A, Ziegler F, Flysjo A, Kruse S, Cancino B, Silverman H (2009) Not all salmon are created equal: life cycle assessment (LCA) of global salmon farming systems. Environ Sci Technol 43:8730-8736

Poore J, Nemecek T (2018) Reducing food's environmental impacts through producers and consumers. Science 360:987-992

Ramos S, Vázquez-Rowe I, Artetxe I, Moreira MT, Feijoo G, Zufía J (2011) Environmental assessment of the Atlantic mackerel (Scomber scombrus) season in the Basque Country. Increasing the timeline delimitation in fishery LCA studies. Int J Life Cycle Assess 16:599-610 
Rebolloso-Fuentes MM, Navarro-Pérez A, García-Camacho F, GuilGuerrero JL (2001) Biomass nutrient profiles of the microalga Nannochloropsis. J Agric Food Chem 49:2966-2972

Roches A, Nemecek T, Gaillard G, Plassmann K, Sim S, King H, Milà I, Canals L (2010) MEXALCA: a modular method for the extrapolation of crop LCA. Int J Life Cycle Assess 15:842-854

Salem N, Eggersdorfer M (2015) Is the world supply of omega-3 fatty acids adequate for optimal human nutrition? Curr Opin Clin Nutr Metab Care 18:147-154

Schade S,Meier T (2020) Distinct microalgae species for food—part 1: a methodological (top-down) approach for the life cycle assessment of microalgae cultivation in tubular photobioreactors. J Appl Phycol. https://doi.org/10.1007/s10811-020-02177-2

Seves SM, Temme EHM, Brosens MCC, Zijp MC, Hoekstra J, Hollander A (2016) Sustainability aspects and nutritional composition of fish: evaluation of wild and cultivated fish species consumed in the Netherlands. Clim Chang 135:597-610

Smárason BÖ, Ögmundarson O, Árnason J, Björnsdóttir R, Davidsdóttir B (2017) Life Cycle Assessment of Icelandic Arctic Char fed three different feed types. Turk J Fish Aquat Sci 17:79-90

Smetana S, Sandmann M, Rohn S, Pleissner D, Heinz V (2017) Autotrophic and heterotrophic microalgae and cyanobacteria cultivation for food and feed: life cycle assessment. Bioresour Technol 245:162-170
Templeton DW, Laurens LML (2015) Nitrogen-to-protein conversion factors revisited for applications of microalgal biomass conversion to food, feed and fuel. Algal Res 11:359-367

Vázquez-Rowe I, Moreira MT, Feijoo G (2010) Life cycle assessment of horse mackerel fisheries in Galicia (NW Spain): comparative analysis of two major fishing methods. Fish Res 106:517-527

Volkmann H, Imianovsky U, Oliveira JLB, Sant'Anna ES (2008) Cultivation of Arthrospira (spirulina) platensis in desalinator wastewater and salinated synthetic medium: protein content and aminoacid profile. Braz J Microbiol 39:98-101

World Health Organization (WHO) (2007) Food and Agriculture Organization of the United Nations, United Nations University. Protein and Amino Acid Requirements in Human Nutrition. Geneva, Switzerland

Zaimes GG, Khanna V (2013) Microalgal biomass production pathways: evaluation of life cycle environmental impacts. Biotechnol Biofuels $6: 1-11$

Ziegler F, Winther U, Hognes ES, Emanuelsson A, Sund V, Ellingsen H (2012) The carbon footprint of Norwegian seafood products on the global seafood market. J Ind Ecol 17:103-116

Publisher's note Springer Nature remains neutral with regard to jurisdictional claims in published maps and institutional affiliations. 